Article

\title{
Blue Sublime and the Time of Capital
}

\author{
Filippo Menozzi
}

Department of English, Liverpool John Moores University, Liverpool L3 5UZ, UK; F.Menozzi@ljmu.ac.uk

Received: 16 March 2020; Accepted: 22 July 2020; Published: 4 August 2020

\begin{abstract}
This essay proposes a concept of the "blue sublime" in order to address how the contradictions of capitalist accumulation regimes manifest themselves in the hydrosphere. My argument starts from the fact that capitalism entails a shift in the imagination of the sea: from the point of view of commodity production and consumption, the sea has turned into field of extraction, resource to be exploited or waste disposal site. But capitalism also involves circulation, which casts the sea into a space of contradictions. On the one hand, the oceanic expanse can be an image for the flow of capital and commodities, and a privileged route that has been central to the mercantile expansion of the world economy. On the other hand, however, the sea can become the emblem of the limit to accumulation, and the ultimate barrier to capital's self-expansion. The blue sublime, hence, provides an image for picturing the totality of capitalism, while in its materiality it embodies capitalism's contingency and perishability. From this point of view, the blue sublime registers a process described by Marx as the "annihilation of space by time" proper to the universalizing tendency of capital. Through a reading of Marx's Grundrisse, the blue sublime hence provides a tangible representation of the asymptotic tendency of capital to reach a zero time of circulation and a privileged location to grasp the material contradictions of a global modernity.
\end{abstract}

Keywords: sublime; capitalism; Marx; the sea; circulation; accumulation of capital

\section{Capitalism and the Sea}

The sea has been a central component in the origins and history of capitalism. Neither finance nor merchant capital can be detached from the world of the sea, while the development of ocean navigation technologies has played a key part in establishing asymmetry and inequality on a global scale (Braudel [1979] 1992, p. 385). The early forms of mercantile capital, in particular, relied on the sea as a vector of transportation for the exchange of goods; seas and oceans also provided a crucial setting and a channel for the capitalist and colonial expansion of Europe. As Cesare Casarino writes in Modernity at Sea, even if the passage from mercantile to industrial capitalism entailed a shift from the ship to the factory as central locus of production of wealth ${ }^{1}$, this does not mean that seas and oceans ceased to be central to the political economy of capitalism. Casarino writes:

During the emergence and consolidation of industrial capitalism, the sea became an increasingly turbulent, contradictory and contested terrain. The world of the sea (namely, the fishing industry, sea travel, sea warfare, and, above all, sea commerce) had occupied the central position in the functioning of mercantile capitalism ... The world of the sea under industrial capitalism ... became, if anything, more important than ever for the functioning

1 The role of merchant capital in the origins of capitalism has long been debated among critics. Brenner (1993) Merchants and Revolution deals with these issues in the aftermath of the so-called "Brenner Debate," showing the importance of colonial trade and the plantation economy in the rise of a new merchant class. Ellen Meiksins Wood reconsiders Brenner's book in her essay "Capitalism, Merchants and Bourgeois Revolution" (Wood 1996). 
of an international political economy that was now for the first time coming into being as a tendentially global capitalist system. (Casarino 2002, p. 3)

Casarino shows how the sea is intimately connected to the question of capitalism's intensive and extensive logic of expansion. From field of circulation of commodities and trade, the growth of financial and industrial capital (and, today, the neoliberal formation of Exclusive Economic Zones) has turned the sea into a resource to be extracted in the production process. It is center stage on discourses of economic development, biodiversity, the enclosure of the commons, labor rights, and sustainability (Dalla Costa and Chilese 2014). As Philip Steinberg notes in an essay on the "maritime mistique", it could be argued that there are at least three images of ocean space: "the ocean as a resource-rich (but fragile) arena for sustainable development, as an (ideally) empty space facilitating friction-free movement of capital, and as a space that is materially irrelevant but whose image provides 'historical' grounding for postindustrial cities" (Steinberg 1999, p. 407). Allan Sekula and Noel Burch write in their notes on their film "The Forgotten Space" that the sea remains "an integral component of the world-industrial system", where the material reality of the global economy is revealed in the globalised industrialism of cargo handling and logistics (Sekula and Burch 2010). In his pivotal study of slavery and finance capital in the Atlantic, Ian Baucom argues for an approach that incorporates "the border zones of exchange, to the slave ships, colonies, and plantations" (Baucom 2001, p. 71). The space of the sea, indeed, gives rise to the "asterisk" subject-formations described by Christina Sharpe in her response to Sekula and Burch in her book In The Wake, where she defines a Trans*Atlantic space of commodification but also resistance and transgression ${ }^{2}$.

In the early twenty-first century, in addition to these competing images of sea space, the blue element is increasingly pictured as the site of a rift between humans and nature and the apocalyptic scale of capitalism's attendant destruction of biodiversity and ecosystems. Accordingly, the hydrosphere is becoming an increasingly contested ground in an era marked by what John Bellamy Foster has described as "ecological imperialism". As Foster and Clark write, "ecological imperialism has resulted in the appropriation of the global commons (i.e., the atmosphere and oceans) and the carbon absorption capacity of the biosphere, primarily to the benefit of a relatively small number of countries at the center of the capitalist world economy" (Foster and Clark 2009, p. 194). The enclosure of seas and oceans in the long-term history of modernity cannot be detached from the regime of exploitation at the heart of what Foster has described as the "metabolic rift" triggered by the spreading out of capitalism (Foster et al. 2010). The logic of profit results in the destruction of nature's capacity of self-renewal, and the severing of the metabolic transformation that should accompany the consumption of natural resources through labor: accumulation provokes a rift in marine metabolism (Clausen and Clark 2005). The hyper-exploitation of environments cannot be de-linked from an unsustainable spiral of accumulation and the global inequality between a few nations at the center and the periphery of the world-system and the continuing regimes of exploitation of labor (Niblett 2019; Paye 2019). Oceans and seas are the setting where the violence of capitalism vividly surfaces: the effects of the metabolic rift result in the process narrated by Ellis (2003) as the "emptying of the ocean"—species extinction, the annihilation of marine life, corals, fish, and the rising water temperatures. Rivers, oceans, and seas have also long been the site of trade and circulation of commodities: the sea, in particular, has been a pathway for the geographical expansion of capitalism on a global scale through international trade since the sixteenth century. The ocean also provides, as Christopher Connery suggests, the sublime figure of a "global space, or international space, a constitutive outside to landedness that became hegemonic by the end of the nineteenth century" (Connery 2001, p. 177); a European invention that, in the history of a capitalist modernity, "came to function as capital's myth element" (p. 179). The oceanic sublime,

2 "The asterisk speaks to a range of configurations of Black being that take the form of translation, transatlantic, transgression, transgender, transformation ... trans-Mediterranean, transubstantiation (by which we might understand the making of bodies into flesh and then into fungible commodities" (Sharpe 2016, p. 30). 
indeed, offers a figure to think the ungraspable totality of capital as a boundless, constantly expanding and threatening whole. The marine element, however, as Connery notes in his discussion of the American sublime in an earlier essay, might also incorporate a resistance to signification:

Perhaps, though, the ocean is too external: its assimilability, even to the flexible and contingent pragmatism of American sublimity, is always in doubt. The solidity of even the vasters American prairie ... allows conversion into images of sublimity that the ocean does not. (Connery 1996, p. 290)

The blue sublime provides a figure to think the operations of capital, but also a limit and a breakdown of those same operations when the sublime figure emerges in its full materiality. While, on the level of form, the blue sublime provides an image for the totality of capitalism and its history of expansion, as a material element the blue sublime also indicates the ultimate destruction and perishability of historical capitalism.

\section{Marx and the Blue Sublime}

In an important passage of Grundrisse, Marx describes the process whereby the development of capitalism as a system of circulation entails the annihilation of space by time. When capitalism systemically expands to regions previously untouched by the exchange of commodities, geographical distance becomes a barrier to profit, because it requires labor and hence more fixed and variable capital: infrastructure building, transportation costs, and expenditure of money to reach faraway markets. This is what Marx defined as the "circulation time" of capital. As Marx explains, circulation time is a "barrier to the productivity of labor $=$ an increase in necessary labor time $=$ a decrease in surplus labor time $=$ a decrease in surplus value $=$ an obstruction, a barrier to the self-realization process [Selbstverwertungsprozess] of capital" (Marx [1939] 1993, p. 539). Every moment spent in order to put a commodity into the market, that is, in the condition that enables the commodity to generate surplus value, is a slowing down, and an impediment to the process of accumulation. The time a commodity needs to reach potential customers needs to be as short and as cheap as possible: every postponement, every quantity of labor necessary to make the commodity travel, is wealth subtracted from the overall profit made out of the production process. Thus, Marx notes, "while capital must on one side strive to tear down every spatial barrier to intercourse, i.e., to exchange, and conquer the whole earth for its market, it strives on the other side to annihilate this space with time, i.e., to reduce to a minimum the time spent in motion from one place to another" (ibid.).

This is a key feature of what Marx defined as the "universalizing tendency" of capital: the paradox at the heart of this universalizing tendency is that the more capitalism expands geographically, the more it annihilates space. David Harvey famously described this occurrence in The Condition of Postmodernity as the "space-time compression" (Harvey 1989, p. 240) or the shrinking of space through the increasing level of the subsumptive powers of capital. This compression is the byproduct of a shift in production determined by capitalism; as Marx indicates, the more production "comes to rest on exchange value, hence on exchange, the more important do the physical conditions of exchange-the means of communication and transport-become for the costs of circulation" (Marx [1939] 1993, p. 524). This is the case because capital inherently "drives beyond every spatial barrier. Thus, the creation of the physical conditions of exchange - of the means of communication and transport-the annihilation of space by time- - becomes an extraordinary necessity for it" (ibid.). An economic system based on capital implies that products are sold in distant markets in large quantities, and transportation costs become a vital component and a necessary factor for realizing the value embodied in the commodity. Marx's analysis continues in his formulation of the issue in Grundrisse:

All labor required in order to throw the finished product into circulation-it is in economic circulation only when it is present on the market—is from capital's viewpoint a barrier to be overcome-as is all labor required as a condition for the production process ... The sea 
route, as the route which moves and is transformed under its own impetus, is that of trading peoples $\varkappa \alpha \tau^{\prime} \grave{\varepsilon} \xi o x \eta ́ v$ [par excellence]. (Marx [1939] 1993, p. 525)

In such a passage, it is remarkable that Marx mentions "the sea route" as a particular kind of spatial presupposition to the circulation of commodities that "moves and is transformed under its own impetus" (ibid.). The sea is different from all other means of transportation because it does not require the same sort of infrastructure building as transportation on land. Just after mentioning the sea, Marx refers to other modes of transportation, such as roads and railways, and the fact that capitalists will only pay for the construction of such infrastructure if it is a profitable enterprise. Marx writes: "Capital as such —its being posited with the necessary scope-will produce roads only when the production of roads has become a necessity for the producers, especially for productive capital itself; a condition for the capitalist's profit-making" (Marx [1939] 1993, p. 530). If building highways, railways, canals, and other channels of transportation is not profitable in itself, e.g., not helping the increase in profit, the capitalists will not embark on such projects. Rather, these will be outsourced to the community, the state, or, as in the case of the colonies, bonded or enslaved labor will be used to create the roads as exchange value so that they can generate revenues.

The mention of the "sea route" as a self-moving and self-transforming route is both an exception and an example of the general argument made by Marx about the function of space as barrier to valorization. The sea, from this point of view, would be less of a barrier than transportation on land, and an optimal background to ensure the continuous, uninterrupted, and smooth process of the creation and realization of value. Indeed, Marx emphasizes how a continuous and uninterrupted "circulation appears as an essential process of capital", as he writes in Grundrisse:

The production process cannot be begun anew before the transformation of the commodity into money. The constant continuity of the process, the unobstructed and fluid transition of value from one form into the other, or from one phase of the process into the next, appears as a fundamental condition for production based on capital to a much greater degree than for all earlier forms of production. (Marx [1939] 1993, p. 535)

The appearance of the sea, in passing, as an example of unobstructed, fluid transition of products and capital in Marx's schema of circulation opens an interesting question about the representation of the blue element in a capitalist age. On the one hand, oceans and seas appear to be an ideal route for trade, hence a much better space for circulation rather than land, and the cradle of merchant capital, which played an important role in establishing capitalism as a global system of exchange and hence a world economy. On the other hand, however, the sea is here just an example within Marx's wider argument about space being a barrier to circulation, and hence the necessity for space to be annihilated by time within a capitalist system of value production. In this context, distance becomes, under capitalism, an obstacle and a barrier, and for this reason Marx concludes:

The more developed the capital, therefore, the more extensive the market over which it circulates, which forms the spatial orbit of its circulation, the more does it strive simultaneously for an even greater extension of the market and for greater annihilation of space by time. (Marx [1939] 1993, p. 539)

The global extension of capitalism does not result in a total spatialization of the globe: the total conquest of space means that the temporal factor is primary, and space can only be seen as a quantity of time or an element of expenditure in the calculation of value. A capitalist only considers how long will it take for a commodity or capital to reach its destination and hence to realise the value it bears by being exchanged. The ultimate aim of capital, as shown by the velocity of financial transactions today and the rise of debates on "accelerationism" (Boys 2014), is the total annihilation of space, because space means time to be spent. As Marx also writes in the second volume of Capital, in a short chapter focused on circulation time: 
The expansion and contraction of the time of circulation operate therefore as negative limits to the contraction or expansion of the time of production or of the extent to which a capital of a given size functions as productive capital ... the more the time of circulation is equal to zero, or approaches zero, the more does capital function, the more does its productivity and the self-expansion of its value increase. (Marx [1885] 1978, p. 204)

In the chapter devoted to commercial or merchant capital in volume 3 of Capital, Marx also shows that the process of circulation creates no value, and even that there is an inverse ratio between rate of profit and the duration of the circulation period. Merchant capital, as the capital invested in circulation, can at most help indirectly to augment surplus value, but the circulation period in itself is an impediment to the process of accumulation (Marx [1894] 1981, pp. 379-93). As Stavros Tombazos notes in his pivotal study of time in Marx, the temporality of the circulation of capital is not incremental and linear, but rather cyclical and repetitive (Tombazos 1994, p. 193).

Circulation time is hence merely a moment or a period in the schema of reproduction of capital. For this reason, a fully developed capitalist system tends to decrease these periods or moments as much as possible, in order to increase the process of valorization. As capital strives asymptotically to reach a zero time of circulation, no distance or gap can be left that might inhibit profit, and the smooth circulation of commodities means reducing the globe to pure temporality. This logic reveals what commentators such as Antonio Negri have described as a contradictory aspect of the expansion of capital. Negri writes in his commentary on Grundrisse:

Time and space, after constituting the fabric of capital's expansion in circulation, appear now as barriers, as obstacles. As obstacles to be eliminated, destroyed-by reducing space to time, by imparting to time the quickness of transfers and transformations ... And capital is forced within these determinations. It must get rid of them in order to release its own potency-and again, always, the possibility of subversion. (Negri 1991, p. 115)

Space and time, like the productive forces of society, become an obstacle to the circulation and valorization of capital. The annihilation of space by time is simultaneously what allows capital to expand and to grow, and the constant re-apparition of a negative limit to capitalism's own logic. Circulation does not merely concern space and time, writes Negri, but also the composition of labor and society. It is for this reason that the site of capitalism's war against space, against labor and against the earth is also the place where possibilities of subversion might arise. There emerges what Negri pictures as a "logic of separation": the constant and seemingly boundless expansion of capital "does not consist of a solution of some sort, but, on the contrary, it consists of the reopening of the separation, in the endless re-positing of the obstacle" (Negri 1991, p. 116). The expansive logic of capital, the annihilation of space by time and hence the universalizing tendency of capital involve an antagonistic logic of separation whereby the obstacle to expansion constantly reappears. As Rosa Luxemburg showed in The Accumulation of Capital, the paradox is that the expansion of capitalism constantly destroys the conditions that make its expansion possible in the first place (Luxemburg [1913] 2003).

Along these lines, in a pivotal essay on the sea and capitalism, Liam Campling and Alejandro Colás remark that the "terraqueous territoriality" of the seas is both the site of friction-less and seamless transit of goods and capital and a contested, uneven terrain that constantly posits obstacles to circulation. In Campling and Colás' words, the specific "geo-physical attributes of the sea, which arguably make it more resistant than land to being transformed into a 'second nature'" (Campling and Colás 2018, p. 3), make the sea a privileged site for engaging with the contradictions of capital:

The sea is both a crucial site for the valorization of capital-be it through extraction or transport-and a major bio-physical obstacle to its reproduction. It is simultaneously a natural resource and an arena of contested social relations; a realm of movement and freedom which nonetheless has been host to the most sophisticated regimes of hierarchical captivity-be these slaving vessels of the past or today's factory fishing ships. (Campling and Colás 2018, p. 22) 
The problem hence concerns the fact that the sea is different from other fields of commodity circulation, at the same time favoring the flows of capital and hindering them. The hydrosphere reveals some key underlying factors in the historical expansion of capitalism as a system of inequality and exploitation. In the process of the accumulation of capital, the sea too must become time, and must take part in the striving for a zero time of circulation, in order for capital to grow. As a space imposing barriers and natural limits on the fast and fluid movement of commodities, the sea too must be "annihilated" by time. There is an important shift occurring through Marx's analysis of the universalizing tendency of capital. Space moves from being a condition of possibility for the expansion of capitalism as a system to being its ultimate limit and point of breakdown. This contradiction suggests that the imagination of the sea as element of a capitalist modernity is trapped in the contradiction of a sublime, un-representable passage from space to time.

\section{The Dialectic of the Blue Sublime}

How do Marx's thoughts on the temporality of capital affect the imagination and experience of the blue element in an era of global capitalism? The dialectical contradiction of the sea as, on the one hand, condition of possibility in the development of the global economy and, on the other hand, ultimate natural barrier and point of breakdown, could align the marine environment to the tradition of aesthetic thinking of the sublime after Immanuel Kant. Indeed, the Kantian structure of the sublime designates, as Fredric Jameson notes, a way of thinking "the question of representation itself, so that the object of the sublime becomes not only a matter of sheer power and of the physical incommensurability of the human organism with Nature", but also "the limits of figuration and the incapacity of the human mind to give representation to such enormous forces" (Jameson 1992a, p. 42). The dialectic of the sublime captures the transition from the blue element as a specific space-ecosystem, trade route, waste disposal site- to an allegorical perception of the sea as the mark of the transformation of the globe into a state of pure temporality. The barrier that the sea represents, indeed, is not just geographical but rather historical: the sublimity of the ocean shows that capitalism cannot expand indefinitely in a smooth and linear teleology of accumulation. The blue sublime signals, for this reason, the passage from seeing the sea as a space, to understanding it allegorically as a figuration of the heterogeneous and non-linear historicity of capitalism as a system. The blue sublime embodies the dialectic of space and time of an age in which capitalism increasingly shows that it is a contingent and perishable system caught in a permanent and destructive state of crisis.

Marx's reflections on the annihilation of space by time can be affiliated with the Kantian tradition of picturing the ocean in relation to the feeling of the sublime, which stems from an influential passage from the analytics of the sublime included in Critique of Judgment. In this famous passage, Kant described the oceanic expanse as sublime only if seen, as he wrote, as "poets do", that is, not as object of knowledge but rather as it appears to immediate perception. Kant notes that "we must be able to see sublimity in the ocean, regarding it, as the poets do, according to what the impression upon the eye reveals", that is, Kant continues, "in its calm, a clear mirror of water bounded only by the heavens, or, be it disturbed, threatening to overwhelm and engulf everything" (Kant [1970] 2007, p. 100). The perception of a sublime hydrosphere involves a form of feeling described by Paul de Man, in his pivotal reading of the materialism of Kant's Critique, as "material vision" (De Man 1996, p. 82). In contrast to the sublime nature of British Romantic poetry such as the vision of the ocean in Wordsworth's "Tintern Abbey", the Kantian sublime is restricted to a purely material level and allows no transition from the material to the ideal (ibid.). There is no reconciliation between nature and humans, mind and body, or the sensuous and the intellectual. In Kant's sublime ocean, perception stops at the material level and remains forever trapped in this separation and breakdown of teleological or purposeful apprehension. Interestingly, Kant opposes the sublime vision of the ocean to other ways of seeing the liquid expanse as "spacious realm of aquatic creatures" as the "mighty reservoirs" of vapors that "fill the air with clouds", or an element that "promotes the greatest commercial intercourse" between continents (Kant [1970] 2007, p. 100). In order to be seen as sublime, the ocean cannot be an object 
of scientific knowledge, economic resource, or trading and transportation route. Any utilitarian or objectifying approach needs to be abandoned, and what is left is a pure experiential encounter with the unrepresentable materiality of the element. As Hartley (2003, p. 23) notes, the Kantian sublime is an "abyss that opens up and threatens to swallow us", which is "nothing but the abyss of discourse itself. Our primary mode of relating to the world is through representation, and representation itself must operate within the limits of our discursive understanding." In Hartley's important study, this "abyss of representation" is the fundamental structure of the sublime that links Kant to our contemporary age.

Sublimity involves, in the Kantian tradition, the acknowledgement of a fundamental inadequacy of empirical powers of presentation, but also the awareness that such limit and inadequacy intimates the presence of something greater and loftier than sensory perception. The sensory presence can, in a capitalist age, be linked to the "real abstractions" produced by capital. This extra-sensory element, however, does not reveal a metaphysical entity, but rather what Alberto Toscano describes as the "open secret" of real abstraction, "one that is to be discerned in the operations of capitalism rather than in an ideological preoccupation with the concrete truth or hidden essence that the abstractions of capital supposedly occlude" (Toscano 2008, p. 286). For Kant, this totality was meant to indicate human reason and freedom. The sublime is hence intimately linked to the awareness of human freedom as only existing within the limits of a "negative presentation". Kant notes: "though the imagination, no doubt, finds nothing beyond the sensible world on which it can lay hold, still this thrusting aside of the sensible barriers gives it a feeling of being unbounded; and that removal is thus a presentation of the infinite. As such it can never be anything more than a negative presentation" (Kant [1970] 2007, p. 104). In particular, the sublime has to do with the perception of a totality that the perceiver is unable to grasp or represent in one intuition, a totality that cannot be reduced to the realm of sensory perception or image. In the influential formulation by Kant, "ideas cannot be presented":

But if we enlarge our empirical faculty of representation with a view to the intuition of nature, reason inevitable steps forward, as the faculty concerned with the independence of the absolute totality, and calls forth the effort of the mind to make the representation of sense adequate to this totality. (Kant [1970] 2007, p. 98)

This blockage of presentation is also the site where the human imagination reveals its supersensible vocation and the intuition of a greater power in the glimpse of an "absolute totality". Irreducible to sensory perception and literally unrepresentable, the ocean sublime hence signals the appearance of an elusive totality that goes beyond, and is aprioristically independent from, bodily perception. This totality is, in Kant, a realm of freedom that can never be fully attained, an infinity of reason that becomes, in Ernst Bloch's reading of Kant, an infinite deferment that "makes the world an ocean without a shore" in which no arrival is possible (Bloch 2000, p. 178). Thus, in Lyotard's commentary of Kant's analytic of the sublime, "the raging ocean is simply hideous ... when taken perceptively. If it arouses a sublime emotion, it does so insofar as it refers thought negatively to a higher finality, that of an Idea" (Lyotard [1991] 1994, p. 69). The ocean is not sublime in itself, but only when its materiality points, even if negatively, to an unrepresentable and non-sensuous totality. In Marx's account, however, the totality that the sea route represents is not, as in Kant, the bearer of utopian horizons, the realm of freedom and the infinite openness of reason. Rather, the totality that the ocean inadequately hints at is the material history and political economy of a singular modernity dominated by capitalism. As Shapiro $(1985$, p. 228) notes in his study of the sublime in Marx, capital shows a tendency "toward a continuous and monstrous development in which every boundary of measure is left behind". Like the Kantian sublime, Shapiro continues, "capital can expand indefinitely as an objective and threatening presence" (p. 228). Marx, however demonstrated how the sublime appearance of capital is in truth a human construction, "which can be modified or displaced by other human acts" (Shapiro 1985, p. 228). In his study of Kant, Michael Wayne suggests that in the sublime, "the principles that the imagination has borrowed from reason for the beautiful now enter into crisis as a radical new sense of temporality enters the aesthetic. A linear and evolutionary sense of time is cancelled in the sublime and this is conveyed by the breakdown in the sensuous apprehension" (Wayne 2014, p. 207). Wayne 
shows how the Kantian sublime anticipated a Marxist way of thinking "of the sublime from the start as a relationship with our productive powers and social relations" (p. 207). The Kantian structure of the sublime remains significant today as a lens to analyze the historicity of capitalism and its impact on societies and environments. The material sublimity of the ocean becomes a particular kind of "geopolitical aesthetic": the ocean appears as that sort of "sound barrier", as Fredric Jameson would explain it, "undetectable save in those moments in which a representational task or program suddenly collapses" (Jameson 1992b, p. 4). The oceanic expanse does not allow habitation or return into the empirical reality and sensory perception. The ocean is a breakdown of cognitive mapping that shows how the totality of capitalist modernity cannot be objectified in a single intuition. The trading route has become a wall and an impenetrable materiality wherein time appears as the supreme elemental force at work in the landscape.

In order to expand on these considerations of the blue element as sublime manifestation of the historicity of capitalism, I will now consider the representation of the Atlantic in a text by critic and philosopher Paul Virilio, Bunker Archaeology. The Atlantic, as Jairus Banaji notes, is probably the place that mostly embodies the maritime origins of a modern world economy: "the building of an Atlantic economy was not just a 'pre-condition' for the growth of capitalism in Europe or Eurasia but embodied the embrace of capital through its own forms of capital accumulation. Even the slave trade generated the networks of merchant capitalism" (Banaji 2018, p. 149). In a text originally published in 1967, which accompanies and introduces his 1975 photographic exhibition of Atlantic Wall fortifications at the Center Pompidou, Paul Virilio devotes some important reflections to his first encounter with the sea. The Atlantic Wall is a system of fortifications built in the early 1940s by Nazi Germany in the attempt to counter the Allies' attack from the sea. It consists of bunkers, observation posts, gun casemates, and shelters, which were meant to prevent the Allies from gaining a foothold in Europe. This kind of disposable architecture was meant to be part, as Paul Hirst notes, of a huge plan of fortification, running from the North Cape to the Spanish border (Hirst 1997, p. 12). Virilio's preface to the collection of photographs included in Bunker Archaeology is simultaneously critical and poetic, both a theory of coastal architecture and an exercise in intimate maritime recollection. Virilio's preface illuminates some crucial qualities of the sea and, most importantly, the phenomenological experience of encountering what he portrays as a "liquid continent".

Virilio's reflections on his encounter with the sea also suggest the ways in which modernity entails a shift in the concept of territoriality. Military technology developed during the Second World War occupies an important place in Virilio's theory of territory. Indeed, in an essay included in Negative Horizon, Virilio expands the trajectory of the annihilation of space under capitalism into a theory of territoriality and war that offers an informative complement to his memories in Bunker Archaeology. Virilio notes:

The place of war is no longer the frontier that bounds the territory, but that point where the machine of transport moves. And with the beginning of the Second World War, General Guderian, practitioner of the Blitzkrieg, concluded: "where we find the tanks, there is the front" ... All is front from this point on, since everything is mobilised at all times and in all terrains ... the country has disappeared in the non-place of the State of emergency, territorial space vanishes, only Time remains. (Virilio [1984] 2005, p. 59)

Militarism reveals, in Virilio's account, its nature as province of the accumulation of capital. Total war, and the dislocation of territory it implies, also turns spatial coordinates into pure temporality. What matters is the ability to reach a point in a short amount of time, a focus on transportation rather than fixed loci on a map. In Bunker Archaeology, Virilio narrates how, in the immediate aftermath of World War II, he managed for the first time to access the sea, trespassing the wall of fortifications that the Germans had built in France as a defensive line against the Allies. After the Liberation, the bunkers that constellate France's Atlantic coastline were abandoned by the army and left behind as a reminder of the not-so-distant past of total war they embodied. Virilio dwells on the specific experience of 
visiting the seaside in Brittany for the first time in 1945, and then again in the 1950s, and the striking impression the ocean made upon him on these occasions. Virilio writes:

With the barriers removed, you were henceforth free to explore the liquid continent; the occupants had returned to their native hinterland, leaving behind, along with the work site, their tools and arms. The waterfront villas were empty, everything within the casemates' firing range had been blown up, the beaches were mined, and the artificers were busy here and there rendering access to the sea. The clearest feeling was still one of absence: the immense beach of La Baule was deserted, there were less than a dozen of us on the loop of blond sand, not a vehicle was to be seen on the streets; this had been a frontier that an army had just abandoned, and the meaning of this oceanic immensity was intertwined with this aspect of the deserted battlefield. (Virilio [1975] 2009, p. 9)

The encounter with the "oceanic immensity" before him is intertwined with the specific historical circumstances of disarmament taking place at the time. The representation of the ocean is part of a wider shift in the technologies of war and territory taking place in the twentieth century. The sea appears only through a deserted coastline still bearing the marks of the war. The element is not figured through the immediacy of a natural space or the landmarks of a place, and Virilio's reference to the immensity of the ocean cannot be removed from the perception of the sea as background to military operations. Virilio's description continues, highlighting the features of the natural landscape:

The weather was superb and the sky over the low ground was starting, minute by minute, to shine. This well-known brilliance of the atmosphere approaching the great reflector was totally new; the transparency I was so sensitive to was greater as the ocean got closer... the expanse of the oceanic horizon was truly surprising: could such a vast space be void of the slightest clutter? Here was the real surprise: in length, breadth, and depth the oceanic landscape had been wiped clean. Even the sky was divided up by clouds, but the sea seemed empty in contrast ... My loss of bearings was proof that I had entered a new element; the sea had become a desert ... sun and ocean had become a magnifying glass scorching away every relief and contrast. (Virilio [1975] 2009, pp. 9-10)

The appearance of the ocean is characterized by transparency, reflection, and an utter absence of figure, shape, or shadow. The ocean is a sort of "new element" in which the narrator is lost, a "great reflector" and "magnifying glass" that prevents any meaningful apperception or comprehension of the spatial coordinates before him. This is a sort of sublime experience, wherein the ideal of the sublime would coincide with a breakdown of representation and impossibility of clear and definite location in space. The sea, in Virilio's account, is by no means a trading route: rather, the trading route has become a wall and an impenetrable materiality wherein time appears as the supreme elemental force at work in the landscape. What emerges in Virilio's description of the Atlantic, in the end, is that the sea represents a materialized time exceeding the circulation time of capital. The temporal element gains momentum in the concluding parts of Virilio's preface to Bunker Archaeology, as he writes about his walk on the banks of Festung Europa (Fortress Europe):

This continuous band of dunes and pebbles and the sharp crest of the cliffs along the coast fit into a nameless country where the three interchanges were glimpsed: the oceanic and aerial space along with the end of emerged land ... A long history was curled up here. These concrete blocks were in fact the final throw-offs of the history of frontiers, from the Roman limes to the Great Wall of China; the bunkers, as ultimate military surface architecture, had shipwrecked at lands' limits, at the precise moment of the sky's arrival in war; they marked off the horizontal littoral, the continental limit. History had changed course one final time before jumping into the immensity of aerial space. (Virilio [1975] 2009, p. 12)

The sea operates, in Virilio's description, also as the setting for an historical shift: the coastline bunkers built by the Germans appear in this context as the last vestige of a history of territorial 
demarcation. The tideline, the point of encounter between land and sea assumes a profound historical significance. It is, at the same time, ruin and vestige of a disappearing age of territoriality and the first anticipation of a new phase in militarist logistics: the coastline of the Atlantic Wall becomes an anticipation of the opening of the skies as site of war and commerce. Beyond their spatial significance, the sublime aspect of the blue element coincides with a sort of historical sublime, in which multiple temporalities appear to coexist in a single instant. Virilio further dwells on this temporal dimension embodied by the abandoned bunkers on the shoreline:

These objects had been left behind, and were colorless; their gray cement relief was silent witness to a warlike climate. Like in certain works of fiction-a spacecraft parked in the middle of an avenue announcing the war of the worlds, the confrontation with inhuman species-these solid masses in the hollows of urban spaces, next to the local schoolhouse or bar, shed new light on what "contemporary" has come to mean. (Virilio [1975] 2009, p. 12)

Virilio's memories connect the representation of the sea to a meditation on the meaning of being contemporary that could remind one of philosopher Ernst Bloch's concept of non-contemporaneous contradiction or ungleichzeitigkeit (Bloch [1962] 1991, p. 113): the time of modernity is not so much a synchronization or leveling out of multiple times into a smooth "space" of circulation. Rather, the history of modernity entails a proliferation of temporalities, overlaps between past and future, and the unevenness described by philosopher Massimiliano Tomba through his image of the "strata of time", wherein different historical epochs combine in the systemic totality of the world economy (Tomba 2015). Virilio's rethinking of the meaning of being contemporary is guided by a walk on the shoreline. The sea, as a bad infinity and ungraspable absence of bearings, inspires a consideration on the temporality of modernity. Virilio concludes:

What was the nature of the modernness in these historical ruins? Could war be prospective? During my trips along European coasts, I grew more and more selective, picking up only traces of the defensive system. Everyday life at the seaside had disappeared. The space I was charting with surveys and measurements of different types of casemates was the space of a different historical time than that of the moment of my trip; the conflict I perceived between the summer of seaside bathing and the summer of combat would never again cease. For me the organization of space would now go hand in hand with the manifestations of time. (Virilio [1975] 2009, p. 14)

The experience of the sea becomes, for Virilio, the encounter between clashing temporalities: present, past, and future coexist in a dense and contradictory setting rich in historical traces but also anticipations and prospective intimations of the future. On a shoreline punctuated by bunkers left behind by previous generations, Virilio feels the present disappear in order to make room for a future in the past. The "manifestations of time" captured in this description, indeed, are simultaneously retrospective and anticipatory. Quintessentially modern, the ruins experienced by Virilio populate the coastline with a temporality of survival and prophecy. The bunkers situate modernity as a thing of the past, a relic, a remnant, and a crypt, while they also locate, paradoxically, modernity in the future, as aperture of events that have not yet happened. Archaeology is hence mediated by the complex historicity of changing regimes of territoriality, militarism, and technology: punctuated by residual architectures at the same time left over and prospective, the encounter with the great reflector is hence stretched onto a plane of temporal dislocation and amplification.

\section{Conclusions: The Times of the Sea}

Narrative and philosophical representations of the sea can disclose key aspects at the heart of a global modernity marked by the universalizing tendency of capital. In particular, the process described by Steinberg (2001) as the "social construction of the ocean" needs to be connected to the rise of capitalism as a global system and the changes in the perception of the blue element deriving from 
economic forms including merchant, industrial, and financial capital. The way in which the sea is narrated, perceived, and inhabited is not simply reducible to its ecological aspects, but also belongs to the superstructural realm of culture as productive force in society. As Sharae Deckard writes in a pivotal essay, neoliberalism involves a specific kind of "hydroculture, referring not to hydroponic cultivation, but rather to the cultural forms and figurations corresponding to the enclosure and appropriation of water" (Deckard 2019, p. 111). In these regimes of hydroculture, Deckard suggests, "water functions as a thematic element, but also as representation and symbolic regime, product and producer of the contingent socio-ecological relations stabilizing the neoliberal disposition" (ibid.). The contemporary experience of the blue element cannot be detached from the temporality produced by an expanding capitalist modernity. As a trading route that played a central role in the establishment of capitalism as a system through mercantilism, the sea is coded as smooth and seamless background in the process of annihilation of space by time. However, the hydrosphere is not exhausted by the routes of merchant capital and the increasing asymmetries of a globalized world. Today, marine ecosystems reveal more and more their nature as material barrier and limit to the expansive powers of capital. The blue element appears, from this point of view, simultaneously as a precondition and an obstacle to the systemic drive of the accumulation of capital. The sea embodies the contradictory qualities of an economic system that destroys its conditions of possibility as it increasingly expands and encroaches the globe. In an era of ecological imperialism, emptying of the oceans and destruction of biodiversity, the sublime ocean can only incorporate wider tendencies at work in an economic system posing increasingly deadly and destructive barriers to its own possibilities of reproduction.

Funding: This research received no external funding.

Acknowledgments: I would like to thank the special issue editors Michael Paye and Alexandra Campbell and the anonymous peer-reviewers for their help and feedback.

Conflicts of Interest: The author declares no conflict of interest.

\section{References}

Banaji, Jairus. 2018. Globalising the History of Capital: Ways Forward. Historical Materialism 26: 143-66. [CrossRef] Baucom, Ian. 2001. Specters of the Atlantic. The South Atlantic Quarterly 100: 61-82. [CrossRef]

Bloch, Ernst. 1991. Heritage of our Times. Translated by Neville, and Stephen Plaice. Cambridge: Polity. First published 1962.

Bloch, Ernst. 2000. The Spirit of Utopia. Translated by Anthony Nassar. Stanford: Stanford University Press.

Boys, Benjamin. 2014. Malign Velocities. Accelerationism and Capitalism. Alresford: Zero Books.

Braudel, Fernand. 1992. Civilisation and Capitalism Volume 1. The Structures of Everyday Life. Translated by Sian Reynolds. Berkeley: University of California Press. First published 1979.

Brenner, Robert. 1993. Merchants and Revolution: Commercial Change, Political Conflict, and London's Overseas Traders, 1550-1653. London: Verso.

Campling, Liam, and Alejandro Colás. 2018. Capitalism and the sea: Sovereignty, territory and appropriation in the global ocean. Environment and Planning D: Society and Space 36: 776-94. [CrossRef]

Casarino, Cesare. 2002. Modernity at Sea. Melville, Marx, Conrad in Crisis. Minneapolis: University of Minnesota Press.

Clausen, Rebecca, and Brett Clark. 2005. The metabolic rift and marine ecology: An analysis of the ocean crisis within capitalist production. Organization \& Environment 18: 422-44.

Connery, Christopher L. 1996. The Oceanic Feeling and the Regional Imaginary. In Global/Local: Cultural Production and the Transnational Imaginary. Edited by Wimal Dissanayake and Rob Wilson. Durham: Duke University Press.

Connery, Christopher. 2001. Ideologies of land and sea: Alfred Thayer Mahan, Carl Schmitt, and the shaping of global myth elements. Boundary 2 28: 173-201. [CrossRef]

Dalla Costa, Mariarosa, and Monica Chilese. 2014. Our Mother Ocean: Enclosure, Commons, and the Global 350 Fishermen's Movement. New York: Common Notions. 
De Man, Paul. 1996. Aesthetic Ideology. Edited by Andrzej Warminski. Minneapolis: University of Minnesota Press.

Deckard, Sharae. 2019. Water shocks: Neoliberal hydrofiction and the crisis of 'cheap water'. Studies 16: 108-25. [CrossRef]

Ellis, Richard. 2003. The Empty Ocean. Washington: Island Press.

Foster, John Bellamy, and Brett Clark. 2009. Ecological imperialism: The curse of capitalism. Socialist Register 40: 186-201.

Foster, John Bellamy, Brett Clark, and Richard York. 2010. The Ecological Rift: Capitalism's War on the Earth. New York: Monthly Review Press.

Hartley, George. 2003. The abyss of Representation: Marxism and the Postmodern Sublime. Durham: Duke University Press.

Harvey, David. 1989. The Condition of Postmodernity. Oxford: Blackwell.

Hirst, Paul. 1997. The Defence of Places: Fortification as Architecture [part 2]. AA Files 34: 6-17.

Jameson, Fredric. 1992a. Postmodernism, or the Cultural Logic of Late Capitalism. Durham: Duke University Press. Jameson, Fredric. 1992b. The Geopolitical Aesthetic. Bloomington: Indiana University Press.

Kant, Immanuel. 2007. Critique of Judgment. Translated by James Creed Meredith. Revised by Nicholas Walker. Oxford: Oxford University Press. First published 1970.

Luxemburg, Rosa. 2003. The Accumulation of Capital. Translated by Agnes Schwarzschild. London: Routledge. First published 1913.

Lyotard, Jean-François. 1994. Lessons on the Analytic of the Sublime. Translated by Elizabeth Rottenberg. Stanford: Stanford University Press. First published 1991.

Marx, Karl. 1978. Capital. 2 vols, Translated by David Fernbach. London: Penguin. First published 1885.

Marx, Karl. 1981. Capital. 3 vols, Translated by David Fernbach. London: Penguin. First published 1894.

Marx, Karl. 1993. Grundrisse. Translated by Martin Nicolaus. London: Penguin. First published 1939.

Negri, Antonio. 1991. Marx beyond Marx. Lessons on the Grundrisse. Translated by Harry Cleaver, Michael Ryan, and Maurizio Viano. Edited by Jim Fleming. New York: Autonomedia.

Niblett, Michael. 2019. "Time's carcase": Waste, labor, and finance capital in the Atlantic world-ecology. Atlantic Studies 16: 72-89. [CrossRef]

Paye, Michael. 2019. Beyond a Capitalist Atlantic: Fish, Fuel, and the Collapse of Cheap Nature in Ireland, Newfoundland, and Nigeria. Irish University Review 49: 117-34. [CrossRef]

Sekula, Allan, and Noel Burch. 2010. Notes for a Film. Available online: https://www.theforgottenspace.net/static/ notes.html (accessed on 1 April 2020).

Shapiro, Gary. 1985. From the Sublime to the Political: Some Historical Notes. New Literary History 16: $213-35$. [CrossRef]

Sharpe, Christina. 2016. In the Wake: On Blackness and Being. Durham: Duke University Press.

Steinberg, Philip. 1999. The maritime mystique: sustainable development, capital mobility, and nostalgia in the 374 world ocean. Environment and Planning D: Society and Space 17: 403-26. [CrossRef]

Steinberg, Philip. 2001. The Social Construction of the Ocean. Cambridge: Cambridge University Press.

Tomba, Massimiliano. 2015. Marx's Temporalities. Leiden: Historical Materialism/Brill.

Tombazos, Stavros. 1994. Time in Marx. Leiden: Historical Materialism/Brill.

Toscano, Alberto. 2008. The open secret of real abstraction. Rethinking Marxism 20: 273-87. [CrossRef]

Virilio, Paul. 2005. Negative Horizon. Translated by Michael Degener. London: Continuum. First published 1984. Virilio, Paul. 2009. Bunker Archaeology. Princeton: Princeton Architectural Press. First published 1975.

Wayne, Michael. 2014. Red Kant: Aesthetics, Marxism and the Third Critique. London: Bloomsbury.

Wood, Ellen Meiksins. 1996. Capitalism, Merchants and Bourgeois Revolution: Reflections on the Brenner Debate and Its Sequel. International Review of Social History 41: 209-32. [CrossRef]

(C) 2020 by the author. Licensee MDPI, Basel, Switzerland. This article is an open access article distributed under the terms and conditions of the Creative Commons Attribution (CC BY) license (http://creativecommons.org/licenses/by/4.0/). 